\title{
Current knowledge of earthworm richness and distribution in Santa Fe province, Argentina
}

\author{
Carolina Elisabet Masin ${ }^{1}$, Fernando Roberto $\mathrm{Momo}^{2}$, Cristina Susana Zalazar ${ }^{1}$ \\ \& Alba Rut Rodríguez ${ }^{3}$ \\ 1. Instituto de Desarrollo Tecnológico para la Industria Química, Güemes 3450, 3000 Santa Fe. Argentina; \\ cemasin@santafe-conicet.gov.ar, szalazar@santafe-conicet.gov.ar \\ 2. Instituto de Ciencias, Universidad Nacional de General Sarmiento, 1613 Los Polvorines, Buenos Aires, Argentina; \\ fmomo@ungs.edu.ar \\ 3. Facultad de Humanidades y Ciencias, Universidad Nacional del Litoral, Paraje El Pozo, 3000 Santa Fe. Argentina; \\ albarutr@santafe-conicet.gov.ar
}

Received 13-II-2018. Corrected 16-V-2018. $\quad$ Accepted 14-VI-2018.

\begin{abstract}
Updated list of earthworms (Oligochaeta: Lumbricina) from Santa Fe (Argentina) is presented in this work, including current data of species richness and territorial distribution status and information collected by Ljungström and collaborators 40 years ago. Field samplings were conducted between 2012 and 2015 at 23 sites, located in 11 of the 19 districts of the province. Earthworms were collected following a standard methodology. The conservation of specimens was done with $4 \%$ formalin solution and their identification was performed according to taxonomy keys. Richness, similarity and complementarity of species between the phytogeographic provinces were analyzed. A total of 15 earthworm species were identified and grouped into ten genera and five families: Acanthodrilidae (Dichogaster bolaui, Microscolex dubius), Glossoscolecidae (Glossodrilus parecis), Lumbricidae (Aporrectodea caliginosa, Aporrectodea rosea, Aporrectodea trapezoides, Bimastos parvus, Eisenia fetida, Octolasion tyrtaeum), Megascolecidae (Amynthas gracilis, Amynthas morrisi, Metaphire californica), Ocnerodrilidae (Eukerria saltensis, Eukerria rosae, Eukerria stagnalis). From all the species found five, G. parecis, E. saltensis, E. rosea, E. stagnalis and M. dubius, are native to South America, and the rest were introduced from Asia and Europe. The Espinal presented the greatest richness of earthworms (12), while the Pampeana showed high values of complementarity (greater than $70 \%$ ) with the Chaco Húmedo and Valle de Inundación del Río Paraná. Endogeic species were present in all environments surveyed. In particular, the exotic species A. trapezoides and A. morrisi showed a wide geographical distribution, having been found at 70 and $50 \%$, respectively, of the total number of the studied sites. One species, E. rosea, which is in the list, was not recorded in the sampling of 40 years ago. The results of current survey show that the number of species was lower compared to study by Ljungström and collaborators ( $60 \%$ of the 23 species registered). Possibly the remarkable change in the richness and distribution of earthworms could be a process associated with changes in soil use and land management developed over 40 years. Rev. Biol. Trop. 66(3): 1171-1181. Epub 2018 September 01 .
\end{abstract}

Key words: Oligochaeta; Lumbricina; biodiversity; native and exotic species; Santa Fe; Argentina.

The first records on earthworms in Argentina date from the $19^{\text {th }}$ century (Michaelsen, 1900; Cognetti de Martiis, 1901), and were primarily of systematic and zoogeographical nature. These studies contributed significantly to knowledge of terrestrial oligochaetes. During the second half of the $20^{\text {th }}$ century, the Brazilian zoologist Gilberto Righi, the Swedish researcher Per-Olf Ljungström and the Argentinian taxonomist Catalina de Mischis were distinguished by their contributions on the oligoquetofauna of Argentina. The studies on earthworms in the province Santa Fe in the 1970's produced information on the taxonomy, distribution and ecology of earthworms (Ljungström, 1971; Ljungström \& Emiliani, 
1971; Ljungström, Orellana, \& Priano, 1973; Ljungström, Emiliani, \& Righi, 1975; Righi, 1979). Such works added interesting contributions on the relevance of earthworms as a natural resource. In this regard, the study "Notas sobre los oligoquetos (lombrices de tierra) argentinos" by Ljungström et al. (1975), consisted of the most complete research work on oligoquetofauna for Argentina, in particular for Santa Fe province.

The last systematic review of earthworms for Argentina was performed by Mischis (2007), who recorded 25 species for Santa Fe province: three species of Glossoscolecidae (Glossoscolex uruguayensis uruguayensis, Glossoscolex uruguayensis ljungstromi), ten species of Ocnerodrilidae (Belladrilus emiliani, Eukerria asuncionis, Eukerria eiseniana, Eukerria halophila, Eukerria saltensis, Eukerria santafesina, Eukerria stagnalis, Eukerria subandina, Ilyogenia comondui, Ocnerodrilus occidentalis), four species of Acanthodrilidae (Dichogaster bolaui, Dichogaster saliens, Microscolex dubius, Microscolex phosphoreus) and seven species of Lumbricidae (Aporrectodea caliginosa, Aporrectodea rosea, Aporrectodea trapezoides, Bimastos parvus, Eisenia fetida, Eiseniella tetraedra tetraedra, Octolasion tyrtaeum). The South American family Ocnerodrilidae was the one that displayed the highest number of species, followed by the exotic family Lumbricidae. This review was based on the previous work of Ljungström et al. (1975) about of oligoquetofauna for Santa Fe.

Forty years later after the publication of the paper of Ljungström et al. (1975), the studies on earthworms in province Santa $\mathrm{Fe}$ are scarce (Masin, Rodríguez \& Maitre, 2011; Maitre, Rodríguez, Masin, \& Ricardo, 2012; Masin et al., 2017).

The aim of the work is to provide updated information on the richness and territorial distribution of the earthworm species in Santa Fe.

\section{MATERIAL AND METHODS}

Study area: The study was conducted in the province of Santa Fe (Fig. 1), which has an area of $133007 \mathrm{~km}^{2}$ and is located in the east-central region of the Republic Argentina, in the south of the American continent. Its north-south axis is $720 \mathrm{~km}$ long, and the eastwest axis is $380 \mathrm{~km}$ long. It is divided into 19 districts and it is an extensive plain that ranges from 10 to 125 masl (Biasatti et al., 2016).

The climate of Santa Fe has two gradients, one thermal from north to south, and another hydric from east to west. Because of its thermal regime, the climate can be defined as temperate without cold season in the south and temperate and warm in the north (average temperatures of $21{ }^{\circ} \mathrm{C}$ and precipitations between 850 and more than $1200 \mathrm{~mm}$ annually). For the hydric regime, it varies from humid to subhumid from east to west (Lewis \& Collantes, 1974).

The main types of vegetation in Santa Fe are included in four phytogeographic provinces and five subdivisions (Cabrera, 1976; Prado, 1993; Dinerstein et al., 1995; Burkart, Bárbaro, Sánchez, \& Gómez, 1999) (Fig. 1):

1. Chaqueña province with two areas: 1A) Chaco Seco: located in the northwest and characterized by water deficit, with predominance of xerophile forests. 1B) Chaco Húmedo: located in the northeast and north central, has higher mean annual rainfall (above $1000 \mathrm{~mm}$ ) and its vegetation includes humid subtropical deciduous forests, savannahs of palm trees and grasslands with various types of wetlands.

2. Espinal province, in the centre, is characterized by the presence of low xerophile forest.

3. Valle de Inundación del Río Paraná province, its main vegetation types are subtropical wet forest, gallery forest, various types of flooded savannas and wetlands (rivers, streams, ponds, marshes and estuaries).

4. Pampeana province in the south is mainly is composed of different types of grasslands.

Collection and identification of earthworms: Earthworms were obtained by field sampling carried out between 2012 and 2015 in 23 sites (Fig. 1), located in 11 out of 


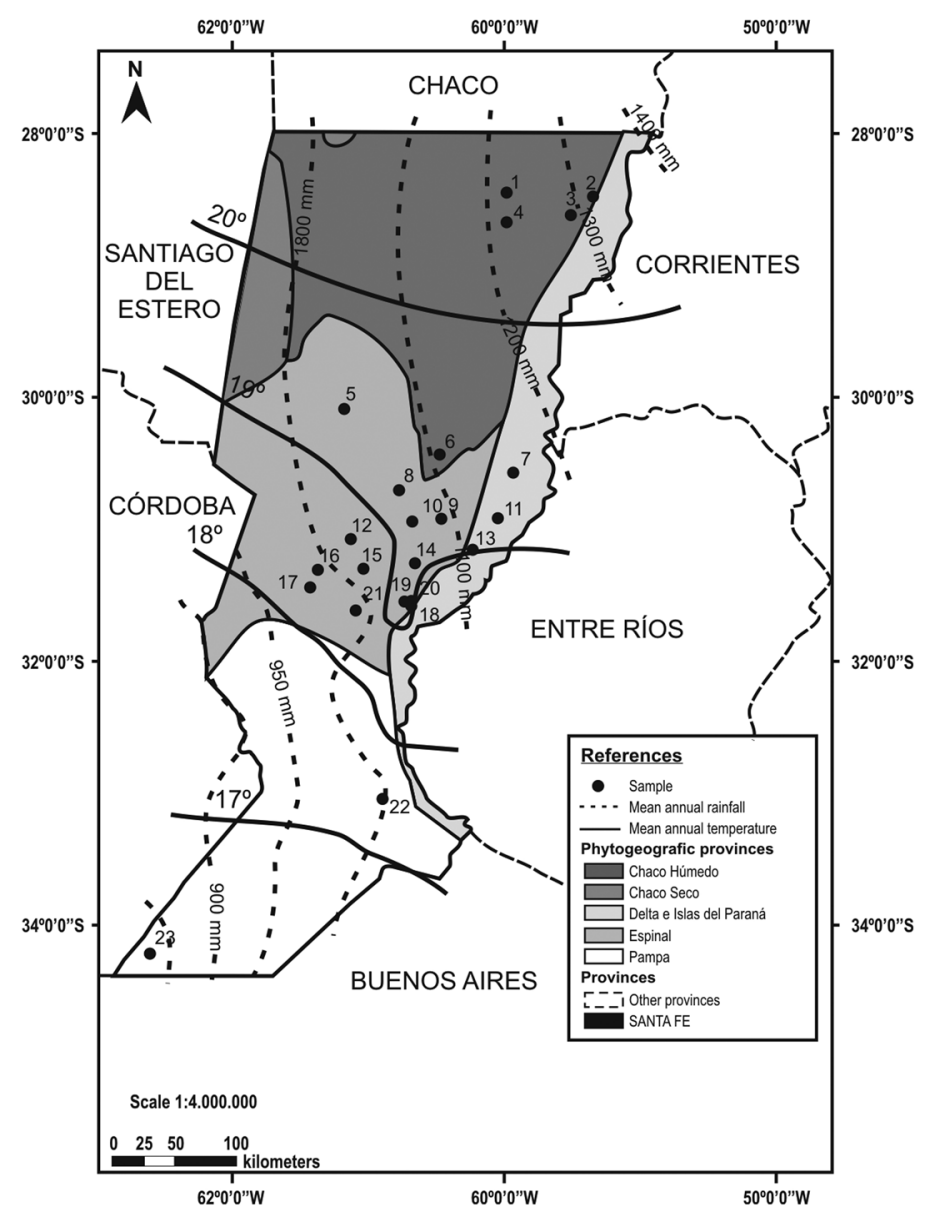

Fig. 1. Sites sampled in Santa Fe during 2012-2015 (Modified from Arzamendia \& Giraudo, 2004). References: 1= Los Tábanos; 2 =Villa Ocampo; 3= El Sombrerito; 4= Tartagal; 5= La Cabral; 6= Colonia Silva; 7= San Javier; 8= San Justo; 9= Naré; 10=Videla; 11= Helvecia; $12=$ Sarmiento; $13=$ Cayastá; $14=$ Laguna Paiva; 15= Grutly; 16= Rafaela; 17= Susana; 18= Monte Vera; 19= Recreo; 20= Ángel Gallardo; 21= San Jerónimo del Sauce; 22= Zavalla; 23= Rufino.

the 19 districts of the province. Earthworms were collected of various environments including agricultural systems (under various tillage management practices), livestock systems, gardens, native grasslands and native forest.

The methodology used was TSBF (Tropical Soil Biology and Fertility) (Anderson \& Ingram, 1993). In each site a total of 40 monoliths were collected during two seasonal instances (20 in autumn and 20 in spring). Each monolith $(30 \times 30 \times 30 \mathrm{~cm})$ was distanced from each other by $15 \mathrm{~m}$ along a transect. The conservation of specimens was done with $4 \%$ formalin solution, and identification was performed according to Mischis (1991), Reynolds (1996) and Blakemore (2005). Moreover, each species was assigned to an ecological group (Bouché, 1977).

The taxonomic, zoogeographical and ecological update of the oligoquetofauna presented included both data provided by Ljungström et al. (1975) as well as de novo data of a Doctoral Thesis (Masin, 2017). The study of Ljungström and collaborators provides a base and reference 
record on oligoquetofauna of Santa $\mathrm{Fe}$, what allows to interpret and compare in a general way with the information of the current survey.

Statistical analysis: The percentage of complementarity was analyzed measuring the degree of difference in composition of species between different communities (Colwell \& Coddington, 1994). Complementarity varies from zero (identical species composition) to one (different composition). Using the SPADE software (Chao \& Shen, 2009), the number of species from the different phytogeographic provinces (Chaco Húmedo, Espinal, Valle de Inundación del Río Paraná, Pampeana) and the number of shared species were calculated.

In addition, the composition of the oligoquetofauna of different phytogeographic provinces was compared by means of a similarity percentage analysis (SIMPER), taking into account the dissimilarity of Bray-Curtis, calculated by means of the PAST ver2.16 program (Hammer, Harper, \& Ryan, 2012).

\section{RESULTS}

Taxonomic richness: A total of 15 species belonging to ten genera and five families were found during field samplings (Table 1). Lumbricidae was the best represented family with $40 \%$ of all species registered, followed by families Megascolecidae and Ocnerodrilidae both with $20 \%$, Acanthodrilidae with 13 $\%$, and finally the family Glossoscolecidae with $7 \%$.

Five species are native to South America (M. dubius, G. parecis, E. rosae, E. saltensis and E. stagnalis), and the other species were introduced (exotic) from North America, Africa, Asia and Europe. The species E. rosae was a new record, being included in the updated earthworm species list of Santa Fe.

Earthworm assemblages and territorial distribution: The sampled Espinal area recorded the highest species richness $(12=E$. rosae, E. saltensis, E. stagnalis, D. bolaui, $M$. dubius, A. gracilis, A. morris, M. californica,
A. rosea, A. trapezoides, B. parvus, O. tyrtaeum $)$ with respect to Chaco Húmedo $(10=E$. saltensis, E. stagnalis, D. bolaui, M. dubiu, A. morris, M. californica, A. caliginosa, A. rosea, A. trapezoides, E. fetida), Valle de Inundación del Río Paraná $(8=E$. stagnalis, D. bolaui, $M$. dubiu, A. morris, M. californica, A. rosea, A. trapezoides, E. fetida) and Pampeana (5 = D. bolaui, G. parecis, A. rosea, A. trapezoides, $O$. tyrtaeum). The assemblage of earthworms in the Pampeana area showed high values of complementarity with both Chaco Húmedo (75\%) and Valle de Inundación del Río Paraná (70 \%). According to the SIMPER analysis, the species that most contributed to the dissimilarity between the communities of the phytogeographic provinces were A. trapezoides and $A$. morrisi. Of the five native species recorded, four: E. rosae, E. saltensis, E. stagnalis and M. dubius, were present in Chaco Húmedo, Espinal and Valle de Inundación del Río Paraná environments.

The species A. trapezoides, A. rosea, A. morrisi, M. californica and E. stagnalis were widely distributed, the species A. trapezoides was found in 11 provincial districts and the other species in seven. Conversely, E. fetida was present in two districts and E. rosea, $A$. gracilis, A. caliginosa, B. parvus and G. parecis were only present in one (Table 1).

Endogeic species were present in all environments surveyed, while epiendogeics in 70 $\%$ of the sites (Table 1).On the other hand, exotic epigeic species such as E. fetida and B. parvus, were found only at $13 \%$ of the sites studied, particularly at horticultural sites use (topsoils with organic matter accumulated little decomposed).

\section{DISCUSSION}

The work of Ljungström et al. (1975) relieved 13 districts, of which 10 were part of the current study (2012-2015). In both, the area studied represented more than $80 \%$ of the total area including a wide latitudinal and longitudinal distribution covered different environments. However, it is important to mention that 
TABLE 1

Earthworm species found in the province Santa Fe during 2012-2015

\begin{tabular}{|c|c|c|c|c|c|}
\hline Family/species & $\begin{array}{l}\text { Native/ } \\
\text { Exotic }\end{array}$ & $\begin{array}{l}\text { Ecological } \\
\text { category }\end{array}$ & $\begin{array}{l}\text { Site/s where it } \\
\text { was found }{ }^{\text {a }}\end{array}$ & $\begin{array}{c}\text { Type of } \\
\text { environment }\end{array}$ & $\begin{array}{c}\text { Number } \\
\text { provincial } \\
\text { districts found }\end{array}$ \\
\hline \multicolumn{6}{|l|}{ OCNERODRILIDAE } \\
\hline Eukerria rosae (Beddard, 1895) & Native & Endogeic & 17 & $\mathrm{R}$ & 1: C \\
\hline Eukerria saltensis (Beddard, 1895) & Native & Endogeic & 5,6 & $\mathrm{~A} / \mathrm{L}, \mathrm{L}$ & 2: SC, SJ \\
\hline Eukerria stagnalis (Kinberg, 1867) & Native & Endogeic & $\begin{array}{l}1,2,3,6,11,13,14 \\
17,18,21\end{array}$ & $\begin{array}{l}\mathrm{L}, \mathrm{H}, \mathrm{A}, \mathrm{A} / \mathrm{L}, \mathrm{R}, \\
\text { FN }\end{array}$ & $\begin{array}{l}\text { 7: GO, G, SJ, } \\
\mathrm{LCa}, \mathrm{V}, \mathrm{C}, \mathrm{LC}\end{array}$ \\
\hline \multicolumn{6}{|l|}{ ACANTHODRILIDAE } \\
\hline Dichogaster bolaui (Michaelsen, 1891) & Exotic & Endogeic & $1,2,4,7,19$ & $\mathrm{~L}, \mathrm{H}, \mathrm{A} / \mathrm{L}, \mathrm{HG}, \mathrm{FN}$ & $\begin{array}{l}\text { 4: GO, V, LCa, } \\
\text { SJa }\end{array}$ \\
\hline Microscolex dubius (Fletcher, 1887) & Native & Epiendogeic & $\begin{array}{l}6,7,9,11,15,18 \\
21,23\end{array}$ & $\mathrm{H}, \mathrm{L}, \mathrm{HG}, \mathrm{A} / \mathrm{L}, \mathrm{A}$ & $\begin{array}{l}\text { 6: SJ, SJa, G, LC, } \\
\text { LCa, GL }\end{array}$ \\
\hline \multicolumn{6}{|l|}{ GLOSSOSCOLECIDAE } \\
\hline Glossodrilus parecis (Righi\& Ayres, 1975) & Native & Endogeic & 23 & A & 1: GL \\
\hline \multicolumn{6}{|l|}{ MEGASCOLECIDAE } \\
\hline Amynthas gracilis (Kinberg, 1867) & Exotic & Epiendogeic & 19 & FN & 1: $\mathrm{LCa}$ \\
\hline Amynthas morrisi (Beddard, 1892) & Exotic & Epiendogeic & $\begin{array}{l}2,3,4,5,6,7,8,10 \\
11,13,14,18,19\end{array}$ & $\mathrm{H}, \mathrm{A}, \mathrm{HG}, \mathrm{A} / \mathrm{L}, \mathrm{FN}$ & $\begin{array}{l}\text { 7: GO, V, SC, SJ, } \\
\text { SJa, G, LCa }\end{array}$ \\
\hline Metaphire californica (Kinberg, 1867) & Exotic & Epiendogeic & $\begin{array}{l}2,4,6,7,11,18 \\
19,21\end{array}$ & $\mathrm{H}, \mathrm{A} / \mathrm{L}, \mathrm{L}, \mathrm{HG}, \mathrm{FN}$ & $\begin{array}{l}\text { 7: GO, V, SJ, SJa, } \\
\text { G, LC, LCa }\end{array}$ \\
\hline \multicolumn{6}{|l|}{ LUMBRICIDAE } \\
\hline Aporrectodea caliginosa (Savigny, 1826) & Exotic & Endogeic & 2 & $\mathrm{H}$ & 1: GO \\
\hline Aporrectodea rosea (Savigny, 1826) & Exotic & Endogeic & $\begin{array}{l}1,2,4,6,9,12,13 \\
15,18,20,21,23\end{array}$ & $\mathrm{~L}, \mathrm{H}, \mathrm{A} / \mathrm{L}, \mathrm{A}$ & $\begin{array}{l}\text { 7: GO, V, SJ, G, } \\
\mathrm{LC}, \mathrm{LCa}, \mathrm{GL}\end{array}$ \\
\hline Aporrectodea trapezoides (Dugès, 1828) & Exotic & Endogeic & $\begin{array}{l}2,3,4,5,6,7,8,9 \\
10,11,12,13,15,16 \\
18,19,21,22,23\end{array}$ & $\mathrm{~A}, \mathrm{~A} / \mathrm{L}, \mathrm{FN}, \mathrm{H}, \mathrm{R}$ & $\begin{array}{l}\text { 11: GO, V, SC, } \\
\text { SJ, SJa, G, C, } \\
\text { LC, LCa, R, GL }\end{array}$ \\
\hline Bimastos parvus (Eisen, 1874) & Exotic & Epigeic & 18 & $\mathrm{H}$ & 1: LCa \\
\hline Eisenia fetida (Savigny, 1826) & Exotic & Epigeic & 2,11 & $\mathrm{H}, \mathrm{L}$ & 2: GO, G \\
\hline Octolasion tyrtaeum (Savigny, 1826) & Exotic & Endogeic & $5,19,21,22,23$ & $\mathrm{~A}, \mathrm{~A} / \mathrm{L}, \mathrm{HG}$ & $\begin{array}{l}\text { 5: SC, LC, LCa, } \\
\mathrm{R}, \mathrm{GL}\end{array}$ \\
\hline
\end{tabular}

References: ${ }^{a}$ See figure 1 to locate the sites. $\mathrm{A}=$ Agricultural, $\mathrm{A} / \mathrm{L}=$ Agricultural $/$ Livestock, $\mathrm{R}=\mathrm{Roadside}, \mathrm{FN}=\mathrm{Forestal}$ Nursery, H= Horticultural, HG= Home garden, L= Livestock. Provincial districts= GO: General Obligado, V: Vera, SC: San Cristóbal, SJ: San Justo, SJa: San Javier, G: Garay, LC: Las Colonias, LCa: La Capital, C: Castellanos, R: Rosario, GL: General López.

neither the specific sites of sampling relieved by Ljungström et al. (1975) nor the information about the type of environmental corresponding to districts were reported. Therefore, a strict comparison between both studies is difficult but it is possible to discuss some similarities and difference.

In both works the same families were recorded: Acanthodrilidae, Glossoscolecidae, Lumbricidae, Megascolecidae, and Ocnerodrilidae, but the number of species in the current 
survey was lower $(60 \%$ of the 23 species reported in the study of 1975) (Fig. 2). An important difference was marked by native species, where the checklist of Ljungström et al. (1975) showed more than $50 \%$ of the total recorded species, against only $33 \%$ reached in the current study. From this percentage the genus Eukerria, particulary E. stagnalis, was the most widespread and this species was generally found in several agroecosystems (Table 1), establishing differences with the study reported 40 years ago (Fig. 3). In addition to this, E. rosae was a new record. Information about this species, and particularly its ecology, is scarce in Argentina. In the current survey $E$. rosea was found in a soil water-saturated of the roadside. The few studies made in Santa $\mathrm{Fe}$, reported that water-saturated biotopes with organic matter from the local vegetation, are usually inhabited by species of the genus Eukerria (Emiliani, Ljungström, Priano, Gutierrez,
\& Calamunte, 1971; Emiliani, de Orellana \& Ljungström, 1973). Also, studies by Feijoo, Quintero, Fragoso \& Moreno (2004) and Grosso \& Brown (2007) state that found species of this genus in muddy soils or with high moisture content and associated with plant roots.

The exotic species $A$. rosea, A. trapezoides, A. morrisi and M. californica were the most widespread. They were present at agricultural sites (crop sites, livestock, mixed croplivestock farming, horticulture) (Table 1). The genus Aporrectodea, particularly A. trapezoides, has a similar spatial distribution compared to that registered 40 years ago, while the megascoelecids $A$. morrisi and $M$. californica significantly increased their area of distribution (Fig. 3 ). These species seem to adapt to the impact of agricultural practices (Feijoo et al., 2004), and may be invasive colonizer / opportunistic, occupying the niche of native species that disappear after environmental transformations

Ljungström et al. 1975
23 species
Dichogaster bolaui
Dichogaster saliens*
Microscolex dubius
Microscolex phosphoreus*
Glossodrilus parecis
Glossoscolex uruguayensis*
Rhinodrilus n.sp.*
Aporrectodea caliginosa
Aporrectodea rosea
Aporrectodea trapezoides
Bimastos parvus
Eisenia fetida
Octolasion tyrtaeum
Amynthas gracilis
Amynthas morrisi
Methapyre californica
Eukerria asuncionis*
Eukerria eiseniana*
Eukerria halophila*
Eukerria saltensis
Eukerria santafesina*
Eukerria stagnalis
Eukerria subandina*
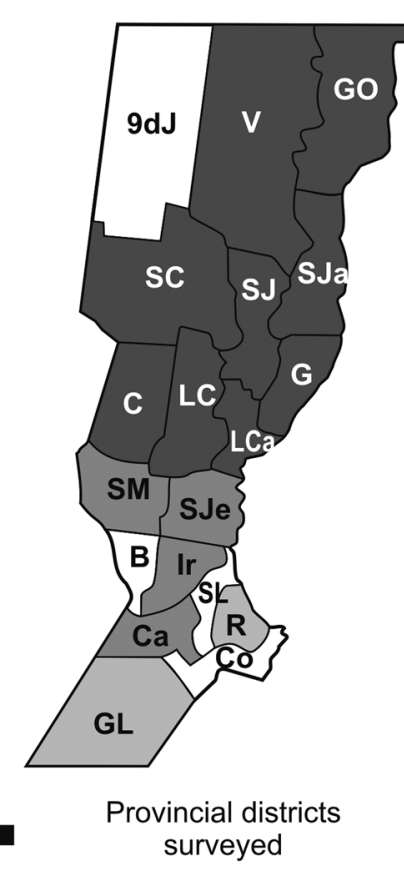

\section{Present study (2012-2015)}

\section{5 species}

Dichogaster bolaui

Microscolex dubius

Glossodrilus parecis

Aporrectodea caliginosa

Aporrectodea rosea

Aporrectodea trapezoides

Bimastos parvus

Eisenia fetida

Octolasion tyrtaeum

Amynthas gracilis

Amynthas morrisi

Methapyre californica

\section{Eukerria rosae \\ Eukerria saltensis \\ Eukerria stagnalis}

Provincial districts surveyed

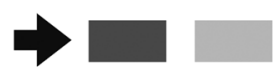

Fig. 2. Earthworm species recorded by Ljungström et al. (1975) and the current survey (2012-2015). References: (*) not found in current sampling, and bold letter new record. Provincial districts in color indicate sampled. Provincial districts = GO: General Obligado, V: Vera, 9dJ: 9 de Julio, SC: San Cristóbal, SJ: San Justo, SJa: San Javier, G: Garay, LCa: La Capital, LC: Las Colonias, C: Castellanos, SM: San Martín, SJe: San Jerónimo, Ir: Iriondo, B: Belgrano, Ca: Caseros, SL: San Lorenzo, R: Rosario, Co: Constitución, GL: General López. 


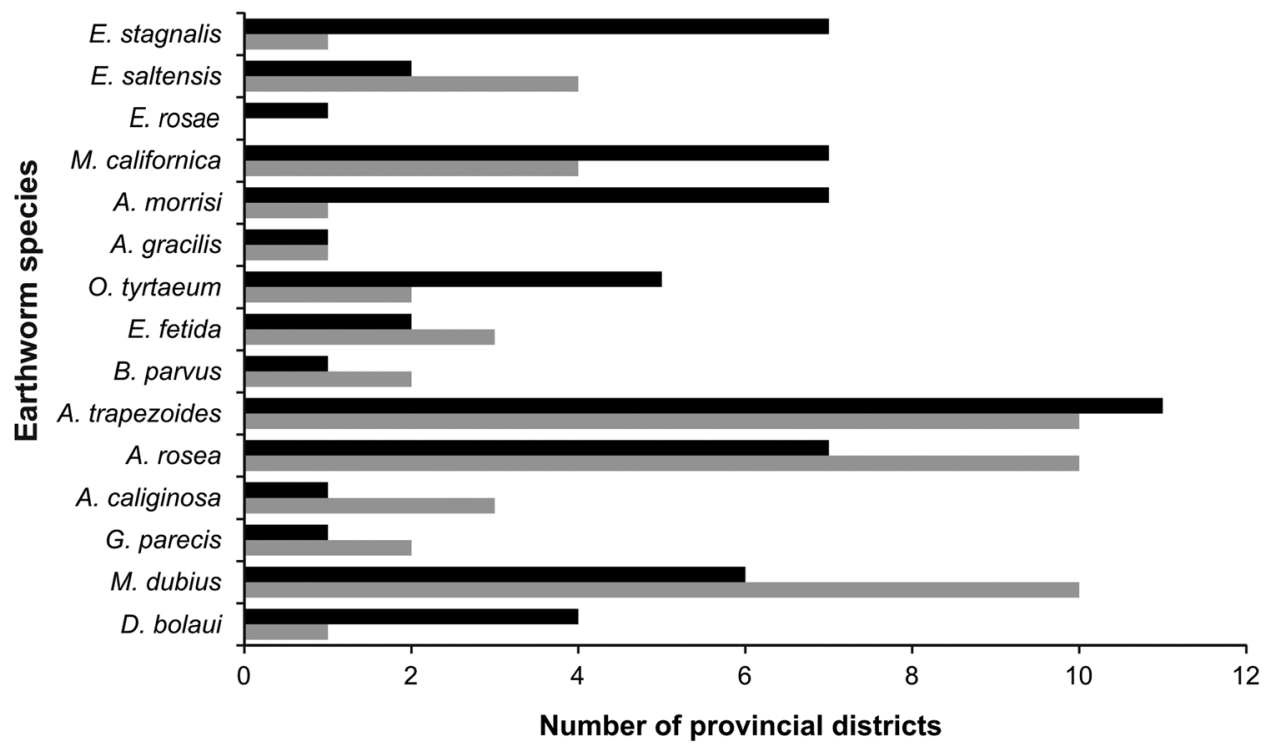

- Present study (2012-2015) ㄴ. Ljungström et al. (1975)

Fig. 3. Earthworm species by provincial districts of province Santa Fe: current survey (2012-2015) and the registry of four decades ago.

such as the replacement of natural vegetation by crop plants (Brown \& James, 2007).

In comparison to the situation four decades ago the current study shows a new picture of earthworm species richness and distribution in the province of Santa Fe. This change can be related to the impact of the increase of agricultural activities, which decreased landscape heterogeneity and modified soil properties considerably.

Figure 4 shows the advance of soybean crops during the last 40 years. This situation has produced changes in landscape diversity. Areas of native forest and natural grassland in

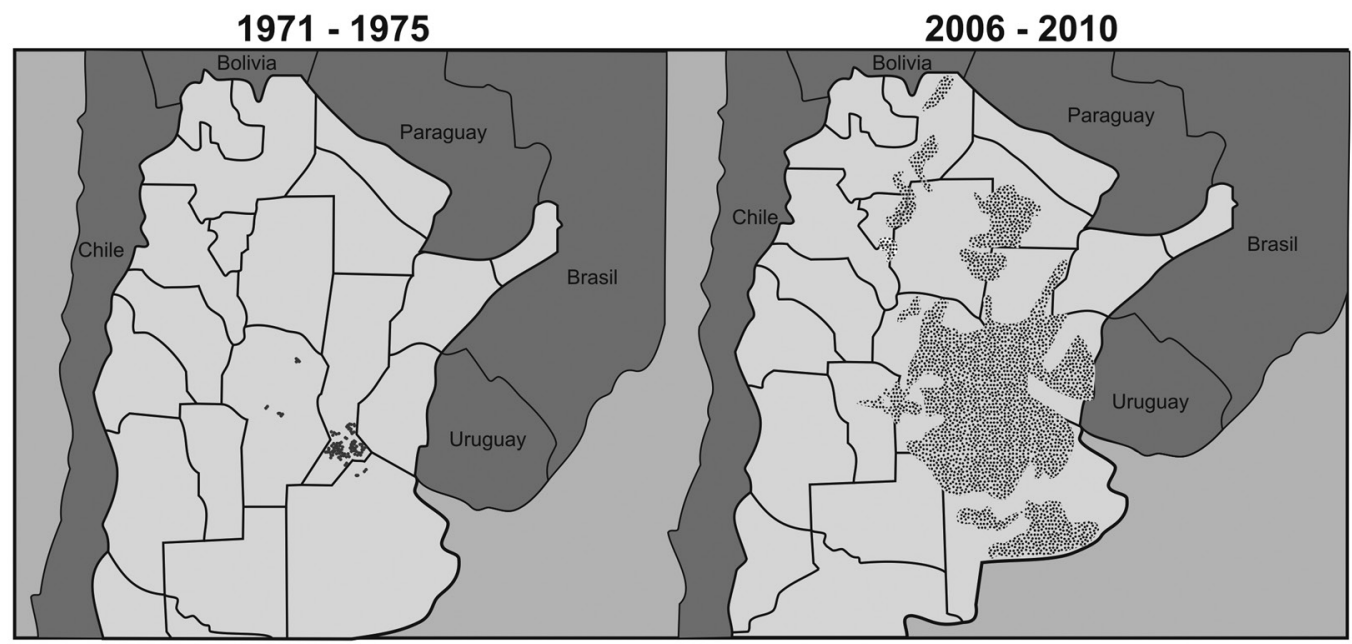

Fig. 4. Advance of agricultural frontier, in particular of soybean crop in Argentina during the last four decades (Modified after CONICET 2012). 
the Central and Northern parts of the province were replaced by agricultural crops, particularly by soybean (Heredia, Giuffré, Gorleri, \& Conti, 2006; Viglizzo et al., 2010; CONICET, 2012). The implementation of continuous agriculture and intensive soil management has resulted in the following consequences: loss of organic matter and nutrients, erosion and thus degradation of soil, resulting in an overall decrease of biodiversity (Miretti, Pilatti, Lavado, \& Imoff, 2012).

When natural grasslands and/or forests are replaced by agroecosystems, changes can occur at the taxonomic (substitution of native species by exotic), ecological (increase or decrease of species number according to ecological categories), or both levels (Fragoso et al., 1999). Consequently, earthworms associated with natural environments, in particular native species, tend to move to other habitats less anthropogenically disturbed (Ramírez Pisco, Guzmán Álvarez, \& Leiva Rojas, 2013). This could be related to the results obtained in this work, where species found previously (Ljungström et al., 1975) in natural areas or with low anthropic intervention were not found anymore, for example the native species M. phosphoreus, G. uruguayensis and some species of the genus Eukerria (Fig. 2). Other native species, such as G. parecis and $M$. dubius, were found in ecosystems with lower levels of anthropogenic disturbance. Finally, species of the Eukerria genus, particularly $E$. stagnalis, were present both in natural environments and agroecosystems with intensive land use (Fragoso et al., 1999).

In agreement with Paoletti (1999); Dupont et al. (2012); Cunha et al. (2016) and OrtizGarmino, Pérez-Rodríguez, \& Ortiz-Ceballos (2016), the distribution of species is strongly influenced by landscape transformation history, in particular the intensity of changes of soil use (Briones, Ostle, McNamara, \& Poskitt, 2009; Tondoh, Guéi, Csuzdi, \& Okoth, 2011). In addition, environmental factors such as climate (temperature, but also soil moisture) act as a limitation for the distribution of earthworms.

In this study, 15 earthworm species belonging to ten genera and five families were found in the province of Santa Fe. One species not known from this province beforehand is Eukerria rosae, a native species to South American. Earthworm assemblages of Espinal, Chaco Húmedo and Valle de Inundación del Río Paraná showed greater similarity, while Pampeana (lower richness) showed high values of complementarity with the three phytogeographic provinces. Within the last 40 years, the pattern of earthworm biodiversity changed considerably in this province, a process which is associated with changes in soil use and land management, in particular the increased cultivation of soy.

\section{ACKNOWLEDGMENTS}

The authors are grateful to John Reynolds (Oligochaetology Laboratory, ON Canada) and Catalina C. de Mischis (Universidad Nacional de Córdoba, Argentina) for their assistance in species identification. We thank María Soledad Cruz, Mariano Demonte and Leticia Vuizot for their help in field work. In addition, authors thank Melina Almada for the statistical advice and the technical assistance of Claudia Romani.

\section{RESUMEN}

Conocimiento actual sobre riqueza y distribución de lombrices de tierra en la provincia de Santa Fe, Argentina. En este trabajo se presenta una lista actualizada de lombrices de tierra (Oligochaeta: Lumbricina) de Santa Fe (Argentina), incluyendo datos actuales de riqueza de especies y estado de distribución territorial e información recolectada por Ljungström y colaboradores hace 40 años. Los muestreos de campo se realizaron entre 2012 y 2015 en 23 sitios, ubicados en 11 de los 19 departamentos de la provincia. Las lombrices fueron recolectadas siguiendo métodos estándar. La conservación de los especímenes se realizó con solución de formalina al 4 \% y la identificación mediante claves taxonómicas. La riqueza, similitud y complementariedad de especies, se analizó entre las provincias fitogeográficas y se identificaron un total de 15 especies de lombrices en diez géneros y cinco familias: Acanthodrilidae (Dichogaster bolaui, Microscolex dubius), Glossoscolecidae (Glossodrilus parecis), Lumbricidae (Aporrectodea caliginosa, Aporrectodea rosea, Aporrectodea trapezoides, Bimastos parvus, Eisenia fetida, Octolasion tyrtaeum), Megascolecidae (Amynthas gracilis, Amynthas morrisi, Metaphire californica), Ocnerodrilidae (Eukerria saltensis, 
Eukerria rosae, Eukerria stagnalis). De todas las especies encontradas, cinco: G. parecis, E. saltensis, E. rosea, E. stagnalis y $M$. dubius, son nativas de América del Sur, y el resto introducidas desde Asia y Europa. Las especies endógeas estuvieron presentes en todos los ambientes estudiados. En particular, las especies exóticas: A. trapezoides y A. morrisi, mostraron amplia distribución geográfica, se encuentran en el 70 y $50 \%$, respectivamente, de los sitios estudiados. Una especie, E. rosea, que está en la lista, no fue registrada en el muestreo de hace 40 años. La zona del Espinal presentó la mayor riqueza de lombrices (12), en tanto que la Pampeana mostró valores altos de complementariedad (mayores al $70 \%$ ) con el Chaco Húmedo y el Valle de Inundación del Río Paraná. Los resultados del relevamiento actual muestran que el número de especies fue menor en comparación con el estudio de Ljungström y colaboradores ( $60 \%$ de las 23 especies registradas). Posiblemente el notable cambio en la biodiversidad del paisaje de la provincia, asociado al uso de la tierra y a la gestión de los sistemas de producción desarrollados a lo largo de 40 años, podría haber influido en la distribución y riqueza de especies de lombrices.

Palabras clave: Oligochaeta; Lumbricina; biodiversidad; especies nativas; especies exóticas; Santa Fe Argentina.

\section{REFERENCES}

Anderson, J. M. \& Ingram J. S .I. (1993). Tropical Soil Biology and Fertility: A Handbook of Methods. Wallingford, UK: CAB International.

Arzamendia, V. \& Giraudo, A. (2004). Usando patrones de biodiversidad para la evaluación y diseño de áreas protegidas: las serpientes de la provincia de Santa Fe (Argentina) como ejemplo. Revista Chilena de Historia Natural, 77, 335-348.

Biasatti, N. R., Rozzatti, J. C., Fandiño, B., Pautaso, A., Mosso, E., Marteleur, G., ... Vallejos, L. (2016). Las ecoregiones, su conservación y las áreas naturales protegidas de la provincia de Santa Fe (p. 244). Santa Fe, Argentina: Ministerio de Medio Ambiente.

Blakemore, R. J. (2005). A Series of searchable texts on earthworm biodiversity, ecology and systematics from various regions of the world. (Vol. 1). Yokohama National University, Japan: Soil Ecology Research Group. Retrieved from http://bio-eco.eis. ynu.ac.jp/eng/database/ earthworm.

Bouché, M. B. (1977). Stratégies lombriciens. In U. Lohm \& T. Persson (Eds.), Soil organisms as components of ecosystems (pp. 122-132). Stockholm, Swedish: Swedish Na.

Briones, M. J. I., Ostle, N. J., McNamara, N. P., \& Poskitt, J. (2009). Functional shifts of grassland soil communities in response to soil warming. Soil Biology and Biochemistry, 41, 315-322.
Brown, G. G. \& James, S. W. (2007). Biodiversidade e biogeografia das minhocas no Estado de Sao Paulo, Brasil. In G. G. Brown \& C. Fragoso (Eds.), Minhocas: biodiversidade e ecología na Amércia Latina (pp. 391-400). Londrina, Brasil: Embrapa Soja.

Burkart, R., Bárbaro, N. O., Sánchez, R. O., \& Gómez, D. A. (1999). Eco-regiones de la Argentina. Buenos Aires, Argentina: Programa de desarrollo Institucional, Componente de Política Ambiental, Administración de Parques Nacionales. Recuperado de https://www.sib.gov.ar/archivos/Eco-Regiones_de la_Argentina .pdf

Cabrera, A. L. (1976). Regiones fitogeográficas argentinas. Enciclopedia Argentina de Agricultura y Jardinería. In W. F. Kugler (Ed.), Enciclopedia argentina de agricultura y jardinería (pp. 1-85). Buenos Aires, Argentina: Acme.

Chao, A., \& Shen, T. (2009). Program SPADE (Species Prediction and Diversity stimation). Retrieved from http:/ / chao.stat.nthu.ed u.tw

Cognetti de Martiis, L. (1901). Oligocheti raccolti dal Dott. F. Silvestri nel Chile e nella Republica Argentina. Bollettino dei Musei di Zoologia e Anatomia Comparata della $R$. Universita di Torino, 16, 1-2.

Colwell, R. \& Coddington, J. (1994). Estimating terrestrial biodiversity through extrapolation. Philosophical Transactions Royal Society B, 345, 101-118.

Consejo Nacional de Investigaciones Científicas y Técnicas (CONICET). (2012). La Argentina en mapas: evolución de la agricultura. Recuperado de http:// www.laargentinaen mapas. com.ar/caste/gale.htm

Cunha, L., Brown, G. G., Stanton, D. W., Da Silva, E., Hansel, F. A., Jorge, G., ... the Terra Preta de Indio Network. (2016). Soil animals and pedogenesis: the role of earthworms in anthropogenic soils. Soil Science, $181,110-125$.

Dinerstein, E., Olson, D. M., Graham, D. J., Webster, A. L., Primm, S. A., Bookbinder, M. P., \& Ledec, G. (1995). A conservation assessment of the terrestrial ecoregions of Latin America and Caribbean. Washington, USA: The World.

Dupont, L., Decaëns, T., Lapied, E., Chassany, V., Marichal, R., Dubs, F., ... Roy, V. (2012). Genetic signature of accidental transfer of the peregrine earthworm Pontoscolex corethrurus (Clitellata, Glossoscolecidae) in French Guiana. European Journal Soil Bio$\log y, 53,70-75$.

Emiliani, F., Ljungström, P. O., Priano, L., Gutierrez, T., \& Calamunte, R. (1971). Sobre la ecología de la Eukerria halpophila (Oligochaeta, Ocnerodrilidae). Boletín de la Real Sociedad Española de Historia Natural, 69, 19-22. 
Emiliani, F., de Orellana, J. A., \& Ljungström, P. O. (1973). Contribución al conocimiento de la ecología de Eukerria eiseniana (Oligochaeta, Acanthodrilidae). IDIA, 29, 50-54.

Feijoo, A., Quintero, H., Fragoso, C., \& Moreno, A. (2004). Patrón de distribución y listado de especies de las lombrices de tierra (Annelida, Oligochaeta) en Colombia. Acta Zoologica Mexicana (n.s.) 20, 2, 197-220.

Fragoso, C., Lavelle, P., Blanchart, E., Senapati, B. K., Jiménez, J. J ., Martínez, M. A., ... Tondoh, J. (1999). Earthworm communities of tropical agroecosystems : Origin, structure and influence of management practices. In P. Lavalle, L. Brussaard, \& P. Hendrix (Eds.), Earthworm Management in Tropical Agroecosystems (pp. 27-55). New York, USA: CAB International.

Grosso, E. G. \& Brown, G. G. (2007). Biodiversidad y ecología de las lombrices de tierra en el Uruguay. En G. G. Brown, \& C. Fragoso (Eds.), Minhocas: biodiversidade e ecología na Amércia Latina (pp. 275-280). Londrina, Brasil: Embrapa Soja.

Hammer, O., Harper, D. A. T., \& Ryan, P. D. (2012). PAST (Paleontological Statistics) version 2.16. Software package for education and data analysis. Paleontología Electrónica, 4, 1-9.

Heredia, O. S., Giuffré, L., Gorleri, F. J., \& Conti, M. E. (2006). Calidad de los suelos del norte de Santa Fe. Efecto de la geomorfología y el uso de la tierra. Ciencia del Suelo (Argentina), 24, 109-114.

Lewis, J. P. \& Collantes, M. B. (1974). La vegetación de la provincia de Santa Fe. Reseña general y enfoque del problema. Boletín de la Sociedad Argentina de Botánica, 15, 343-356.

Ljungström, P. O. (1971). Sistemática de los oligoquetos santafesinos. Revista de la Asociación de Ciencias Naturales del Litoral, 2, 39-42.

Ljungström, P. O. \& Emiliani, F. (1971). Contribución al conocimiento de la ecología y distribución geográfica de las lombrices de tierra (oligoquetos) de la Provincia de Santa Fe (Argentina). IDIA, 19-32.

Ljungström, P. O., Emiliani, F., \& Righi, G. (1975). Notas sobre los oligoquetos (Lombrices de tierra) argentinos. Revista de la Asociación de Ciencias Naturales del Litoral, 6, 1-42.

Ljungström, P. O., de Orellana, J. A., \& Priano, J. J. L. (1973). Infuence of some edaphic factors on earthworms distribution in Santa Fe Province (Argentina). Pedobiologia, 13, 236-247.

Maitre, M. I., Rodríguez, A. R., Masin, C. E., \& Ricardo, T. (2012). Evaluation of earthworms present on natural and agricultural-livestock soils of the Center
Northern Litoral Santafesino, República Argentina. In R. P. Soundararajan (Ed.), Pesticide - Advances in chemical and botanical pesticides (pp. 13-38). Croatia: InTech.

Masin, C. E. (2017). Efectos de largo plazo del uso del suelo sobre la comunidad de lombrices de tierra (Annelida, Oligochaeta) en la provincia de Santa Fe (Tesis doctoral). Universidad Nacional del Litoral, Santa Fe, Argentina.

Masin, C. E., Cruz, M. S., Rodríguez, A. R., Demonte, M. J., Vuizot, L. A., Maitre, M. I., ... Almada, M. S. (2017). Macrofauna edáfica asociada a diferentes ambientes de un vivero forestal (Santa Fe, Argentina). Ciencia del Suelo (Argentina), 35, 21-33.

Masin, C. E., Rodríguez, A. R., \& Maitre, M. I. (2011). Evaluación de la abundancia y diversidad de lombrices de tierra en relación con el uso del suelo en el Cinturón Hortícola de Santa Fe (Argentina). Ciencia del Suelo (Argentina), 29, 21-28.

Michaelsen, W. (1900). Oligochaeta. In Das tierreich. 10: XXIX. Berlín: Friedlánder \& Sohn.

Miretti, M. C., Pilatti, M., Lavado, R. S., \& Imoff, S. C. (2012). Historia de uso del suelo y contenido de micronutrientes en Argiudoles del Centro de la provincia de Santa Fe (Argentina). Ciencia del Suelo (Argentina), 30, 67-73.

Mischis, C. C. (1991). Las lombrices de tierra (Annelida, Oligochaeta) de la Provincia de Córdoba, Argentina. Boletín de la Academia Nacional de Ciencias en Córdoba, 54, 187-237.

Mischis, C. C. (2007). Catálogo de las lombrices de tierra de la Argentina (Annelida, Oligochaeta). En G. G. Brown \& C. Fragoso (Eds.), Minhocas: biodiversidade e ecología na Amércia Latina (pp. 241-246). Londrina, Brasil: Embrapa So.

Ortiz-Gamino, D., Pérez-Rodríguez, A., \& Ortiz-Ceballos, A. I. (2016). Invasion of the tropical earthworm Pontoscolex corethrurus (Rhinodrilidae, Oligochaeta) in temperate grasslands. PeerJ, 1-20.

Paoletti, M. G. (1999). The role of earthworms for assessment of sustainability and as bioindicators. Agriculture, Ecosystems and Environment, 74, 137-155.

Prado, D. E. (1993). What is the Gran Chaco vegetation in South America? A redefinition. Contribution of the study of the flora and vegetation of the Chaco. Candollea, 48, 615-629.

Ramírez Pisco, R., Guzmán Álvarez, M. E., \& Leiva Rojas, E. I. (2013). Dinámica de las poblaciones de 
lombrices en un Andisol sometido a distintos sistemas de uso del suelo. Revista Facultad Nacional de Agronomía, Medellín, 66, 7045-7055.

Reynolds, J. (1996). Earthworm biology and ecology. Lindsay, USA: Sir Sandfo.

Righi, G. (1979). Introducción al estudio de las lombrices del suelo (Oligoquetos Megadrilos) de la provincia de Santa Fe (Argentina). Revista de la Asociación de Ciencias Naturales del Litoral, 10, 89-155.
Tondoh, J. E., Guéi, A. M., Csuzdi, C., \& Okoth, P. (2011). Effect of land-use on the earthworm assemblages in semi-deciduous forests of Central-West Ivory Coast. Biodiversity and Conservation, 20,169-184.

Viglizzo, E. F., Carreño, L.V., Pereyra, H., Ricard, F., Clatt, J., \& Pincén, D. (2010). Dinámica de la frontera agropecuaria y cambio tecnológico. En E. Viglizzo \& E. Jobbágy (Eds.), Expansión de la Frontera Agropecuaria en Argentina y su Impacto Ecológico-Ambiental (pp. 9-16). Buenos Aires, Argentina: INTA. 